\title{
Acute thrombosis in stent as a complication of primary percuta- neous coronary intervention: a case report
}

\section{Kristina Pavlović*, Katija Haklička}

Dubrovnik General Hospital, Dubrovnik, Croatia

\author{
KEYWORDS: myocardial infarction, stent thrombosis, fibrinolysis. \\ CITATION: Cardiol Croat. 2018;13(1-2):56. | https://doi.org/10.15836/ccar2018.56
}

*ADDRESS FOR CORRESPONDENCE: Kristina Pavlović, Opće bolnica Dubrovnik, R. Mišetića 2, HR-20000 Dubrovnik, Croatia / Phone: +385-95-5785-243 / E-mail: kike.pavlovic90@gmail.com

ORCID:Kristina Pavlović, https://orcid.org/0000-0002-2185-6954 • Katija Haklička, https://orcid.org/0000-0003-1561-4833

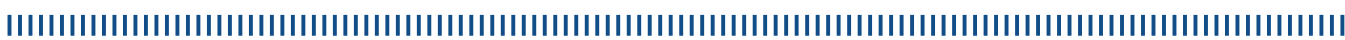

Introduction: Coronary intervention complications refer to ischemic complications and bleeding after intervention. Ischemic are related to a thrombosis in the stent, myocardial infarction in the artery area where the stent is placed and sudden cardiac deaths. Acute thrombosis in the stent is a very serious and fatal complication of percutaneous coronary intervention. It is relatively rare, up to $3 \%$ of patients are affected after the intervention on the coronary artery and occurs within 24 hours. ${ }^{1}$

Case report: We present the case of a 78-year-old man treated in the Coronary Unit of the Dubrovnik General Hospital, who comes to emergency care in the clinical present of unstable angina pectoris, and during treatment develops an acute ST infarction. After admitting in the Coronary Unit, the patient is subjected to an emergency coronary angiography and we diagnosed atherothrombotic occlusion of proximal RCA. With the balloon propagation, the stent is placed over the entire length of the lesion and the control angiogram shows the optimal result. The patient is placed in the Coronary Unit, but within 12 hours the angina occurs with ST-segment elevation, and soon comes a cardiorespiratory arrest. After the patient's intubation and stabilization, we approach to re-coronarography that shows the large thrombotic mass at the RCA and in the pre-set stent is made. PTCA is performed three times, using fibrinolysis and aspirated by aspiration catheter. In the further course of treatment, the condition of the patient is complicated by anemia, renal dysfunction and atrial fibrillation. The patient is released after three weeks in a stable state with recommendations.

Conclusion: Acute thrombosis in the stent, a rare and dangerous complication of primary percutaneous intervention and requires rapid diagnosis and rapid revascularization of the coronary artery.
RECEIVED:

February 1, 2018

ACCEPTED:

February 10, 2018

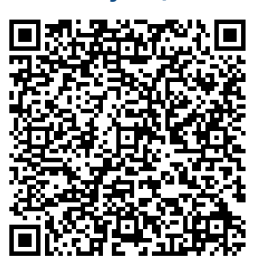

$\square$ Cardiologia Croatica 2018:13(1-2):56.

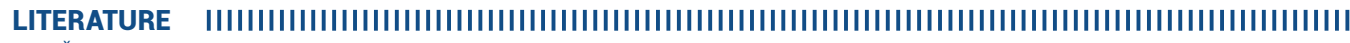

1. Štambuk K. Utjecaj produžene primjene enoksaparina na incidenciju ishemijskih komplikacija i krvarenja u bolesnika nakon ugradnje koronarnog stenta (disertacija). Zagreb: Medicinski fakultet; 2011. Available at: http://medlib.mef.hr/1351/1/Stambuk_K_disertacija_rep_1351.pdf 